\title{
PERAN GURU DALAM MENANAMKAN KARAKTERI DISIPLIN SISWA DI SEKOLAH DASAR NEGERI BLEBER 1 PRAMBANAN SLEMAN
}

\author{
Canggih Kharisma, Suyatno \\ PGSD FKIP Universitas Ahmad Dahlan \\ canggihkharisma4@gmail.com
}

\begin{abstract}
This study aims to describe the planting of Discipline character in Bleber 1 Prambanan Sleman Elementary School, which includes the value of disciplinary characters instilled in the school. Student discipline is formed because of the teacher's leadership role that appropriately applies discipline in school. The teacher also has a role as a role model in implementing discipline. This study included qualitative descriptive research. The research subjects were principals, teachers, and students. The object of research is the role of the teacher in instilling student discipline. The technique of collecting data through interviews, observation, and documentation. The data analysis technique uses the Miles and Huberman models which include data reduction, data presentation, and conclusion drawing. The results of the study showed that the planting of the character of the discipline of students at Bleber 1 Elementary School in Prambanan Sleman was well-created. The role of the teacher in instilling student discipline is as a role model and motivator. As a role model the teacher gives an example to students and as a motivator the teacher always gives advice to students. Supporting factors in instilling discipline in the form of giving gifts as appreciation and punishment as sanctions are very instrumental in regulating the pattern and behavior of students so that they are always orderly in carrying out a discipline. The inhibiting factor in instilling discipline comes from students' internal factors. Discipline is important in order to create a comfortable and safe learning environment in schools.
\end{abstract}

Keywords: The Role of Teachers, Discipline, Character

\begin{abstract}
ABSTRAK
Penelitian ini bertujuan mendeskripsikan penanaman karakter Disiplin di SD Negeri Bleber 1 Prambanan Sleman, yang meliputi nilai karakter kedisiplinan yang ditanamkan di sekolah. Kedisiplinan siswa terbentuk karena peran kepemimpinan guru yang secara tepat menerapkan disiplin di sekolah. Guru juga memiliki peran sebagai suri teladan dalam pelaksanaan disiplin. Penelitian ini termasuk penelitian deskriptif kualitatif. Subjek penelitian adalah kepala sekolah, guru, dan siswa. Objek penelitian
\end{abstract}


adalah peran guru dalam menanamkan sikap disiplin siswa. Teknik pengumpulan data melalui wawancara, observasi, dan dokumentasi. Teknik analisis data menggunakan model Miles dan Huberman yang meliputi reduksi data, penyajian data, dan penarikan kesimpulan. Hasil penelitian menunjukkan bahwa penanaman karakter kedisiplinan siswa di SD Negeri Bleber 1 Prambanan Sleman sudah tercipta dengan baik. Peran guru dalam menanamkan kedisiplinan siswa adalah sebagai role model dan motivator. Sebagai role model guru memberikan teladan kepada siswa dan sebagai motivator guru selalu memberikan nasihat kepada siswa. Faktor pendukung dalam menanamkan kedisiplinan berupa pemberian hadiah sebagai apresiasi dan hukuman sebagai sanksi yang sangat berperan guna mengatur pola maupun tingkah laku siswa agar selalu tertib dalam melaksanakan sebuah kedisiplinan. Faktor penghambat dalam menanamkan kedisiplinan berasal dari faktor internal siswa. Kedisiplinan penting diterapkan guna menciptakan suasana lingkungan belajar yang nyaman dan aman di sekolah.

Kata kunci: Peran Guru, Karakter, Kedislipinan

\section{PENDAHULUAN}

Guru mempunyai peran yang sangat strategis dalam pembentukan pengetahuan, keterampilan, dan karakter peserta didik. Mewujudkan SDM yang mempunyai keterampilan, pengetahuan, dan karakter peserta didik diperlukan sikap disiplin. Kedisiplinan akan terwujud jika kinerja guru dalam hal pengajarannya sesuai dengan standar yang berlaku di sekolah, sehingga dapat menjadi pedoman siswa. Oleh karena itu, kedisiplinan perlu dilaksanakan agar pencapaian tujuan dapat tercapai secara efektif dan efisien. Faktor kedisiplinan peserta didik sebagai sarana untuk menciptakan peserta didik yang berkualitas dan faktor pendidikan sebagai sarana untuk mengembangkan kemampuan para guru. Disiplin sangat penting bagi peserta didik. Oleh karena itu, kedisiplinan harus ditanamkan secara terus-menerus kepada peserta didik. Jika disiplin ditanamkan secara terus menerus, maka disiplin akan menjadi kebiasaan bagi peserta didik. Orang-orang yang berhasil dalam bidangnya masing-masing umumnya mempunyai kedisiplinan yang tinggi. Sebaliknya orang yang gagal, umumnya tidak disiplin. Menurut Huda (2010) pengertian disiplin peserta didik adalah "Suatu keadaan tertib dan teratur yang dimiliki oleh peserta didik di sekolah, tanpa ada pelanggaran-pelanggaran yang merugikan baik secara langsung maupun tidak langsung terhadap peserta didik sendiri dan terhadap sekolah secara keseluruhan". Jadi setiap SDM harus mampu menyiapkan diri dalam hal kedisiplinan. Kedisiplinan siswa di SD Negeri Bleber 1 terbentuk tidak dipungkiri karena peran kepemimpinan guru yang secara tepat menerapkan disiplin di sekolah tersebut. Ketepatan tindakan guru dapat berpengaruh terhadap kedisiplinan siswa dengan baik. Hal ini didukung dengan pendapat Doyle (dalam Danim, 2002) mengemukan dua peran utama guru dalam pembelajaran yaitu menciptakan keteraturan (establishing order) dan memfasilitasi proses belajar (facilitating learning). Keteraturan di sini mencakup hal-hal yang terkait langsung atau tidak langsung dengan proses pembelajaran, seperti : tata letak tempat duduk, disiplin peserta didik di kelas, interaksi peserta didik dengan sesamanya, interaksi peserta didik dengan guru, jam masuk dan keluar untuk setiap sesi mata 
pelajaran, pengelolaan sumber belajar, pengelolaan bahan belajar, prosedur dan sistem yang mendukung proses pembelajaran, lingkungan belajar, dan lain-lain

Guru juga memiliki peran sebagai suri tauladan dalam pelaksanaan disiplin.Teladan guru sangat berperan dalam menentukan kedisiplinan siswa karena guru dijadikan teladan dan panutan oleh para siswanya. Guru harus memberi contoh yang baik, jujur, adil, serta sesuai kata dengan perbuatan. Dengan teladan guru yang baik, kedisiplinan siswa pun akan ikut baik. Jika teladan guru kurang baik (kurang berdisiplin), para siswa pun akan kurang disiplin. Guru jangan mengharapkan kedisiplinan siswanya baik jika dia sendiri kurang disiplin. Guru harus menyadari bahwa perilakunya akan dicontoh dan diteladani siswanya, hal inilah yang mengharuskan guru mempunyai kedisiplinan yang baik agar para siswa pun mempunyai disiplin yang baik pula.

Berdasarkan pengamatan saat berada di SD Negeri Bleber 1 Prambanan Sleman adalah ketika siswa sudah mulai melakukan kedisiplinan yang bagus di lingkungan sekolah maupun di dalam kelas saat pembelajaran. Terlihat saat siswa hadir di sekolah tepat waktu, menjaga kebersihan lingkungan sekolah, tertib melaksanakan upacara, tertib memakai seragam sekolah dan tertib dalam melaksanakan ibadah. Begitupun kedisiplinan siswa juga sudah terbentuk saat berada didalam kelas seperti menyiapkan buku pelajaran sebelum pelajaran dimulai, memperhatikan guru saat menerangkan pembelajaran, mengerjakan dan mengumpulkan PR tepat waktu, menjaga kebersihan kelas, tertib dalam melakukan piket kelas dan tertib membuang sampah pada tempatnya. Terbentuknya kedisiplinan tersebut tentunya adanya peran guru di sekolah yang selalu memberi nasihat dan memberi contoh kepada siswanya untuk melakukan kegiatan disiplin.

Oleh karena itu, untuk melihat lebih jauh ketepatan tindakan seorang guru dan perannya terhadap kedisiplinan siswa di SD Negeri Bleber 1 Prambanan Sleman, Maka tindakan guru di sekolah tersebut akan dilihat dan disesuaikan dengan peran guru. Dengan melihat kesesuaian tindakan guru terhadap situasi terkait dengan siswa dalam menjalankan tugas, fungsi dan tujuan, tentunya dalam hal ini tidak lepas dari perilaku disiplin siswa. Berdasarkan latar belakang masalah diatas, peneliti tertarik untuk mengungkap lebih dalam tentang peran guru di SD Negeri Bleber 1 Prambanan Sleman, Jadi peneliti mengangkat judul "Peran Guru Dalam Menanamkan Karakter Disiplin Siswa di Sekolah Dasar Negeri Bleber 1 Prambanan Sleman".

Sikap disiplin merupakan salah satu faktor yang dapat mempengaruhi prestasi belajar, hal ini sejalan dengan pendapat Anneahira (2012) yang mengungkapkan bahwa: "Dalam dunia pendidikan, kedisiplinan merupakan harga mati yang harus dibayar siswa. Pengaruh disiplin terhadap prestasi belajar sangatlah besar sehingga sangat perlu pengkondisian agar tumbuh dan berkembang sikap disiplin pada pola kehidupan siswa. Karakter merupakan nilai-nilai perilaku manusia yang berhubungan dengan Tuhan Yang Maha Esa, diri sendiri, sesama manusia, lingkungan, dan kebangsaan yang terwujud dalam pikiran, sikap, perasaan, perkataan dan perbuatan berdasarkan norma-norma agama, hukum, tata karma, budaya, dan adat-istiadat (Masnur,2009)

Menurut Isjoni (2009), bahwa pendidik itu bisa guru, orang tua atau siapa saja, yang penting ia memiliki kepentingan untuk membentuk pribadi peserta didik atau anak, Peran guru pada intinya adalah sebagai masyarakat yang belajar dan bermoral. Ada beberapa hal yang perlu dilakukan oleh guru untuk membentuk karakter disiplin pada 
peserta didik. Di antaranya adalah sebagai berikut: 1) Konsisten. 2) Bersifat jelas. 3) Memperhatikan harga diri. 4) Sebuah alasan yang bisa dipahami. 5) Menghadiahkan pujian. 6) Memberikan hukuman. 7) Bersikap luwes. 8) Melibatkan peserta didik. 9) Bersikap tegas. 10) Jangan emosional.

Disiplin sangat penting dan dibutuhkan oleh setiap siswa. Disiplin menjadi prasyarat bagi pembentukan sikap, perilaku dan tata tertib kehidupan berdisiplin, yang akan mengantar seorang siswa sukses dalam belajar. Disiplin yang dimiliki oleh siswa akan membantu siswa itu sendiri dalam tingkah laku sehari-hari, baik di sekolah maupun dirumah. Siswa akan mudah menyelesaikan diri dengan lingkungan yang dihadapinya. Aturan yang terdapat di sekolah akan bisa dilaksanakan dengan baik jika siswa sudah memiliki disiplin yang ada dalam dirinya.

Menurut Amri (2013) Kedisiplinan sebagai alat pendidikan yang dimaksud adalah suatu tindakan, perbuatan yang dengan sengaja diterapkan untuk kepentingan pendidikan di sekolah. Tindakan atau perbuatan tersebut dapat berupa perintah, nasihat, larangan, harapan, dan hukuman atau sanksi. Kedisiplinan sebagai alat pendidikan diterapkan dalam rangka proses pembentukan, pembinaan dan pengembangan sikap dan tingkah laku

Di samping sebagai alat pendidikan, kedisiplinan juga berfungsi sebagai alat menyesuaikan diri dalam lingkungan yang ada. Dalam hal ini, kedisiplinan dapat mengarahkan seseorang untuk menyesesuaikan diri terutama dalam menaati peraturan dan tata tertib yang berlaku di lingkunga itu. Dalam konteks tersebut, kedisiplinan sebagai alat penyesuaian diri di sekolah, yang berarti kedisiplinan dapat mengarahkan siswa untuk menyesuaikan diri dengan cara menaati tata tertib sekolah. Berfungsinya kedisiplinan sebagai alat pendidikan dan alat menyesuaikan diri akan mempengaruhi berlangsungnya kegiatan belajar mengajar di sekolah. Di sekolah yang kedisiplinnya baik, kegiatan belajar mengajar akan berlangsung tertib, teratur, dan terarah. Sebaliknya di sekolah yang kedisiplinnya rendah maka kegiatan belajar mengajarnya juga akan berlangsung tidak tertib, akibatnya kualitas pendidikan sekolah itu akan rendah.

Ada dua faktor penyebab timbulnya tingkah laku dislipin yaitu kebijaksanaan aturan itu sendiri dan pandangan seseorang terhadap nilai itu sendiri. Aturan dibuat untuk dilaksanakan agar tujuan yang diinginkan bisa tercapai. Tidak semua orang setujudengan aturan yang dibuat. Jika aturan dianggap baik, maka kita mau melaksanakan aturan yang ada. Sebaliknya, jika peraturan yang dibuat dianggap tidak baik, maka kita tidak mau menaati peraturan yang dibuat. Aturan yang tidak memiliki sanksi tegas akan membuat orang tidak mematuhi aturan yang ada. Sebaliknya, aturan yang tegas akan membuat orang mematuhinya.

Menurut Trianto (2009), Peranan dalam makna kompleks adalah usaha sadar dari seorang guru untuk membelajarkan siswanya (mengarahkan interaksi siswa dengan sumber belajar lainnya) dalam rangka mencapai tujuan yang diharapkan. Guru merupakan designer (perancang) dalam pendidikan anak. Jadi gurulah yang akan mengelola pengetahuan anak dan gurulah yang dapat membuat anak menjadi seorang yang kreatif ataupun seorang yang malas. Tidak jarang kita mendengar bahwa seorang siswa menampilkan prestasi yang rendah karena ia tidak senang dengan sikap atau tingka laku gurunya. Oleh karena itu sebaiknya seorang guru harus dapat menciptakan suasana yang dapat turut meningkatkan gairah untuk belajar dan berprestasi bagi murid-muridnya. Sebagaimana dijelaskan di atas 
bahwa guru adalah designer atau perancang dalam pendidikan, jadi hasil dari proses belajar mengajar ditentukan oleh kompetensi guru. Guru yang berkompeten akan lebih mampu menciptakan lingkungan belajar yang efektif dan akan lebih mampu mengelolah kelasnya dan hasil belajar siswa akan berada pada tingkat yang optimal (Usman,2008).

Secara umum yang mendasari peranan guru dalam pembelajaran adalah pancasila dan tujuan pendidikan nasional sebagaimana tercantum dalam UUSPN No. 20 tahun 2003, bahwa pendidikan adalah usaha sadar terencana untuk mewujudkan suasana belajar dan proses pembelajaran agar siswa secara aktif mengembangkan potensi dirinya untuk memiliki kekuatan spiritual keagamaan, pengendalian diri, kepribadian, kecerdasan, akhlak mulia, serta keterampilan yang diperlukan dirinya masyarakat bangsa dan Negara (Halimah,2008)

\section{METODE PENELITIAN}

Penelitian ini menggunakan jenis penelitian deskriptif kualitatif Terkait dengan penelitian peran guru dalam membentuk disiplin siswa, informan kunci yang sebaiknya diwawancarai pertama adalah guru kelas. Guru kelas sebagai informan kunci yang pertama karena guru adalah orang yang berwenang dalam mengelola pendidikan dan kegiatan pembelajaran di kelas. Informan selanjutnya yang harus diwawancarai adalah kepala sekolah dan siswa. Berkaitan dengan informan yang berasal darikepala sekolah, guru dan siswa, peneliti tidak memilih semua siswa dan guru untuk dijadikan informan, namun peneliti hanya mengambil sampel siswa dan sampel guru untuk dijadikan informan.

Penelitian ini dilaksanakan di SDN Bleber 1, Jln Karanggede, Sumberharjo, Prambanan, Sleman, Yogyakarta. Waktu penelitian ini dilaksanakan pada bulan JuliAgustus 2017. Subjek penelitian ini adalah kepala sekolah, guru dan siswa di SD Negeri Bleber 1 Prambanan Sleman dalam menerapkan kedisiplinan di sekolah. Objek penelitian ini adalah peran guru dalam menanamkan sikap disiplin siswa di SD Negeri Bleber 1 Prambanan Sleman. Teknik dan instrumen pengumpulan data menggunakan wawancara, observasi dan dokumentasi. Keabsahan data menggunakan triangulasi teknik dan triangulasi sumber. Teknik analisis data menggunakan model Miles dan Huberman yaitu reduksi data, penyajian data dan kesimpulan.

\section{HASIL DAN PEMBAHASAN}

Berdasarkan hasil wawancara, observasi dan dokumentasi diketahui bahwa siswa di SD Negeri Bleber 1 Prambanan sudah melakukan kedisplinan dengan baik. Kedisiplinan siswa di SD Negeri Bleber 1 Prambanan Sleman tercipta karena adanya peran guru. Berikut pembahasan mengenai peran guru dalam menanamkan karakter disiplin siswa di SD Negeri Bleber 1 Prambanan Sleman sebagai berikut:

Penanaman karakter disiplin di SD Negeri 1 Bleber Prambanan sudah terbentuk karena adanya peran guru di sekolah yang selalu memberikan nasehat maupun tindakan dalam menanamkannya. Pembentukan karakter anak memang semestinya dilakukan oleh orang tua. Namun, ketika anak berada di sekolah, maka yang menjadi orang tua anak adalah guru. Sehubungan dengan perannya sebagai pembentuk karakter anak di sekolah, maka guru dituntut untuk sungguh-sungguh menjalankan peran tersebut. Menurut Sinamo (2010:8) guru sebagai teladan dalam pembentukan karakter. 
1. Kesadaran yang dimiliki peserta didik.

Kedisiplinan siswa di SD Negeri Bleber 1 Prambanan Sleman sudah terbentuk adanya peran guru dan kesadaran siswa masing-masing. Seperti saat berangkat sekolah dengan tepat waktu, memarkirkan sepeda dengan rapi, menjaga kebersihan sekolah dan tertib dalam upacara, dan disiplin melaksanakan ibadah. dalam dunia pendidikan, kedisiplinan merupakan harga mati yang harus dibayar siswa. Pengaruh disiplin terhadap prestasi belajar sangatlah besar sehingga perlu pengkondisinan agar tumbuh dan berkembang sikap disiplin pada pola kehidupan siswa. Penanaman karakter disiplin yang positif sejak dini tentunya akan membuahkan kesuksesan dimasa datang. Contohnya seperti datang pada tepat waktu kesekolah, dimasa datang tentunya siswa sudah terbiasa dengan menghargai waktu. Kedisiplinan dalam kebersihan juga sangat penting ditanamkan siswa sejak dini, siswa yang terbiasa menjaga kebersihan disekolah maka akan terbiasa juga menjaga kebersihan di luar sekolah. Adanya kesadaran dalam menjaga kebersihan tentunya kesehatan juga akan didapatkan oleh siswa. Sekolah yang kotor tentunya juga akan mempengaruhi semangat belajar siswa di sekolah. Dalam kedisiplinan kerapian juga tentunya suatu saat akan berdampak positif bagi masa depan siswa suatu saat nanti. Kerapian juga menjadi nilai tambah dalam penilaian seseorang dalam dirinya.

2. Guru memberi teladan bagi siswa.

Guru harus mengetahui tahapan perkembangan siswa sehingga mampu memilih metode pembelajaran yang tepat untuk medidik karakter anak didiknya. Guru juga harus benarbenar mengetahui prinsip-prinsip keteladanan bahwa keteladanan dimulai dari diri sendiri. Di SD Negeri Bleber 1 Prambanan Sleman guru selalu memberikan pembelajaran dengan teori maupun praktek. Hal tersebut terlihat ketika guru memberi pelajaran tentang cara mencuci tangan dengan benar. Guru mencontohkan cara mencuci tangan yang benar lalu siswa mengikutinya. Bukan itu saja, guru juga memberi tauladan dengan membuang sampah pada tempatnya, guru datang tepat waktu, guru berseragam dengan rapi. Adanya tauladan dari guru tentunya siswa juga akan mengikuti perilaku guru tersebut.

Peran guru dalam menanamkan karakter disiplin siswa. Menurut Trianto (2009) peranan dalam makna kompleks adalah usaha sadar dari seorang guru untuk membelajarkan siswanya (mengarahkan interaksi siswa dengan sumber belajar lainnya) dalam rangka mencapai tujuan yang diharapkan. Ada beberapa hal yang perlu dilakukan oleh guru untuk membentuk karakter disiplin pada siswa. Diantaranya menurut Isjoni (2009) adalah

1. Bersifat Jelas

Peraturan Tata tertib yang dibuat oleh pihak sekolah bersifat jelas. Peraturan yang telah disetujui bersama akan ditempel didinding sekolah maupun didalam kelas. Peraturan yang telah dibuat tentunya harus ditaati bersama tanpa terkecuali. Siswa diwajibkan menaati peraturan guna menciptakan karakter yang berkedisiplinan tinggi .

2. Menghadiahkan pujian

Seperti sekolah-sekolah lainnya, Sekolah di SD Negeri Bleber 1 Prambanan Sleman juga memberikan hadiah pujian kepada siswa yang berprestasi maupun siswa yang berkedisiplinan. Tidak hanya pujian saja yang diberikan guru kepada siswa, melainkan hadiah berupa barang alat-alat sekolah dan berupa uang. Hal tersebut bertujuan untuk menumbuhkan semangat antar siswa guna lebih berprestasi dan berkedisiplinan tinggi. 


\section{Memberikan hukuman}

Didalam sebuah peraturan yang berlaku tentnya ada sanksi dan hukuman bagi yang melanggarnya. Sanksi dan hukuman akan disesuaikan dengan pelanggaran yang dilakukannya. Pemberian sanksi atau hukuman tentunya guna memberikan efek jera kepada siswa yang melanggar peraturan. Adanya hukuman tentunya juga menambah kedisiplinan siswa di sekolah. Sanksi dan hukuman tentunya tidak memberatkan siswa karena sudah disepakati bersama. Dalam pemberian hukuman tentunya tidak diberikan langsung oleh guru. Pertama-tama akan diberi nasehat, lalu diberi pengarahan, selanjutnya jika masih diulang-ulang maka tentunya dilakukan penindakan yang tegas.

4. Melibatkan peserta didik

Dalam penanaman karakter yang dilakukan guru kepada siswa tentunya melibatkan siswa didalamnya. Seperti saat upacara bendera, disitu guru mengajarkan disiplin datang tepat waktu, disiplin dalam baris berbaris, disiplin menghargai jalannya upacara, disiplin dalam menghargai makna yang terkandung dalam upacara. Disiplin sekolah, apabila dikembangkan dan diterapkan dengan baik, konsisten dan konsekuen tentunya akan berdampak positif bagi kehidupan dan perilaku siswa. Disiplin dapat mendorong mereka belajar secara kongkret dalam praktik hidup disekolah tentang hal-hal positif, yaitu melakukan hal-hal yang lurus dan benar dan menjauhi hal yang salah. Dengan pemberlakuan disiplin, siswa belajar beradaptasi dengan lingkungan yang baik, sehinga muncul keseimbangan diri dalam hubungan dengan orang lain.

Faktor pendukung dan penghambat dalam menanamkan karakter disiplin. Dalam penanaman kedisiplinan tentunya adanya faktor-faktor yang terjadi, ada faktor pendukung dan faktor penghambat. Faktor pendukung siswa dalam melaksanakan sebuah kedisiplinan adalah keteladanan guru itu sendiri. Menurut Zuriah (2007:7) pepatah guru kencing berdiri, siswa kencing berlari memang benar adanya untuk menunjukkan besarnya pengaruh seorang guru untuk menjadi teladan di lingkungan sekolah maupun diluar sekolah. Apa yang dilakukan guru akan ditiru oleh siswa juga. Kata-kata dan tindakan dari guru akan sangat berarti dalam pembentukan karakter siswa. Hal tersebut sudah terlihat didalam lingkungan SD Negeri Bleber 1 Prambanan Sleman antar guru dan siswa saling berkolaborasi dalam meningkatkan sebuah kedisiplinan. Berikut adalah faktor yang mempengaruhi kedisiplinan

1. Faktor pendukung kedisiplinan

Faktor pendukung untuk meningkatkan sebuah kedisiplinan siswa bisa berupa hadiah sebagai apresiasi dan hukuman sebagai sanksi yang melanggarnya. Siswa yang disiplin baik didalam kelas maupun dilingkungan sekolah tentunya guru tidak segan memberikan hadiah. Hadiah bisa berupa senyuman, pujian dan tepuk tangan. Hadiah yang lebih besar juga bisa berupa uang pembinaan dan bisa berupa barang seperti tas maupun perlengkapan alat tulis sekolah. Adanya hadiah tentunya siswa lebih terpacu untuk meningkatkan kedisiplinannya. Adanya hukuman sebagai sanksi juga sangat berperan guna mengatur pola maupun tingkah laku siswa agar selalu tertib dalam melaksanakan sebuah kedisiplinan.

2. Faktor penghambat kedisiplinan

Faktor penghambat dalam kedisiplinan di SD Negeri Bleber 1 Prambanan Sleman adalah faktor anak itu sendiri. Dalam menanamkan kedisiplinan faktor anak juga perlu 
diperhatikan mengingat memiliki potensi dan kepribadian yang berbeda-beda antara satu dengan yang lain. Pemahaman terhadap individu anak secara cermat dan tepat akan berpengaruh terhadap keberhasilan penanaman kedisiplinan.

Pentingnya penanaman kedisiplinan didalam sekolah. Kedisiplinan penting dilakukan baik disekolah maupun diluar sekolah. Sebuah kedisiplinan akan menentukan sebuah kesuksesan seseorang. Menurut Asmani (2009) disiplin adalah simbol konsistensi dan komitmen seseorang dalam menjalankan tugas dan tanggung jawabnya secara maksimal. Kedisiplinan siswa di SD Negeri Bleber 1 Prambanan Sleman juga akan mempengaruhi hasil belajar siswa didalam sekolah. Seperti siswa disiplin dalam mengerjakan PR, siswa disiplin dalam kebersihan, siswa disiplin dalam beribadah dan siswa disiplin dalam menghargai waktu. Tentunya siswa yang disiplin tersebut akan membuat semangat dalam belajar tumbuh dan berkembang, dibanding dengan siswa yang pemalas dan belum sadar akan sebuah kedisiplinan membuat siswa sering melanggar peraturan yang ada, alhasil kemampuan dalam belajar juga berkurang. Kedisiplinan sejak dini perlu dilakukan guna mempersiapkan mental siswa menjadi kepribadian yang baik.

\section{SIMPULAN}

Penanaman karakter kedisiplinan yang dilakukan siswa di SD Negeri Bleber 1 Prambanan Sleman sudah tercipta dengan baik. Hal tersebut terlihat ketika siswa berangkat ke sekolah lebih awal sebelum jam 7 pagi. Siswa lebih senang datang awal karena ada tugas piket didalam kelas. Siswa datang kesekolah kebanyakan menggunakan sepeda, dan mereka memarkirkannya dengan disiplin. Ketika bel masuk berbunyi maka siswa berbaris didepan kelas untuk menata kerapian siswa baru siswa dengan rapi masuk didalam kelas. Saat pembelajaran berlangsung siswa juga selalu memperhatikan guru dengan antusias. Siswa juga disiplin dalam mengerjakan PR maupun tugas yang diberikan oleh guru. Saat jam istirahat siswa juga tetap menjaga kebersihan dengan membuang sampah pada tempatnya. Pada saat jam pulang, siswa juga disiplin dalam melakukan piket kelas agar kebersihan kelas tetap terjaga. Setiap seminggu sekali juga diadakan bersih-bersih bersama guna membersihkan sekolah.

Peran guru dalam menanamkan kedisiplinan siswa juga sudah tercipta dengan baik. Guru di SD Negeri Bleber 1 Prambanan Sleman selalu menanamkan kedisiplinan dengan tindakan dan nasehat. Guru mensosialisasikan sebuah peraturan kedisiplinan saat upacara bendera, saat pembelajaran dikelas maupun saat ada kegiatan sekolah. Guru selalu memberikan contoh yang nyata dalam kedisiplinan dengan guru hadir lebih awal, guru tertib membuang sampah, guru memberi contoh mencuci tangan yang benar kepada siswa, guru membantu tugas piket kelas saat pulang sekolah, guru memarkirkan kendaraannya dengan tertib. Pemberian contoh tersebut berguna agar siswa juga mencontoh tindakan guru. Karena guru sebagai tauladan oleh siswanya. Jadi apa yang dilakukan guru maka itulah yang akan dicontoh oleh siswa.

Faktor pendukung dalam kedisiplinan di SD Negeri Bleber 1 Prambanan Sleman adalah adanya sebuah hadiah kepada siswa yang berprestasi baik dibidang akademik maupun non akademik. Pemberian hadiah dimaksudkan agar siswa lebih terpacu bersemangat disekolah. Siswa yang berprestasi dan siswa yang memiliki kedisiplinan dengan baik akan diberikan sebuah hadiah dari sekolah maupun dari guru kelasnya. Hadiah 
bisa berupa uang maupun barang seperti alat tulis dan buku sekolah. Selain adanya pemberian hadiah tentunya adanya sebuah hukuman sebagai sanksi siswa yang melanggar sebuah peraturan disekolah. Adanya hukuman tersebut tentunya demi menjaga tingkah laku siswa agar lebih baik. Hukuman yang diberikan juga sangat adil dan tidak memberatkan siswa karena sudah disetujui dari beberapa pihak. faktor penghambat kedisiplinan siswa di SD Negeri Bleber 1 Prambanan Sleman adalah faktor internal dari siswa itu sendiri. Dalam menanamkan kedisiplinan, faktor anak juga perlu diperhatikan, mengingat siswa mempunyai potensi dan kepribadian yang berbeda-beda antara satu dengan yang lain. Pemahaman terhadap individu anak secara cermat dan tepat akan berpengaruh terhadap keberhasilan penanaman kedisiplinan.

Kedisiplinan sangatlah penting bagi para siswa, disiplin bukan hanya untuk menjalankan segala aturan sesuai dengan waktunya melainkan untuk meningkatkan tingkat keberhasilan yang tinggi. Contohnya disiplin waktu, seorang siswa yang menjalankan aktivitas dengan disiplin Ia cenderung akan menghargai waktu dan mengerjakan tugas sesuai waktu yang di tetapkan. Disiplin dalam belajar, siswa akan membagi jadwal belajar dengan efektif, sehingga dalam menjalankan aktivitas belajar, siswa bisa membagi mana yang di prioritaskan terlebih dahulu. Untuk itu siswa di tuntut untuk menjadikan kedisiplinan sebagai budaya dalam meraih keberhasilan. Dalam kebersihan juga terlihat ketika siswa disiplin dalam membuang dan mengelola sampah agar lebih bermanfaat.

\section{DAFTAR PUSTAKA}

Anneahira. 2012. Pengaruh Disiplin Terhadap Prestasi Belajar Siswa. (http://www.anneahira.com/pengaru h-disiplin-terhadap-prestasi-belajar.htm) diakses pada tanggal 6 april 2017.

Amri Sofan. 2013. Pengembangan dan model pembelajaran dalam kurikulum 2013.Jakarta: PT Prestasi Pustakaraya.

Isjoni. (2009). Cooperative Learning. Alfabeta. Bandung.

Masnur Muslich, Pendidikan Karakter Menjawab Tantangan Krisis Multidimensional, (Jakarta: Bumi Aksara,2011)

Moh. Uzer Usman, 2008, Strategi Pembelajaran, Jakarta : Erlangga Nurla Isna Aunillah, Panduan Menerapkan Pendidikan Karakter di Sekolah, (Jogjakarta: Laksana, 2011), .

Nurul Zuriah. 2007. Pendidikan moral\& budi pekerti dalam persspektif perubahan: menggagas platform pendidikan budi pekerti secara kontekstual dan futuristik. Bumi Aksara. Jakarta

Sinamo, Jansen. 2010. Etos Keguruan. Jakarta : Institut Darma Mardika.

Sugiyono. 2014. Metode Penelitian Kuantitatif, Kualitatif, dan Kombinasi (Mixed Methods). Bandung : Alfabeta 
Trianto.2009. mendesain model pembelajaran inofatif progresif (Surabaya:Kencana Prenada Media Group 